PRACE GEOGRAFICZNE

zeszyt $154,2018,127-145$

doi: 10.4467/20833113PG.18.012.9444

Instytut Geografii i Gospodarki Przestrzennej UJ

Wydawnictwo Uniwersytetu Jagiellońskiego

\title{
PASAŻERSKI TRANSPORT KOLEJOWY NA OBSZARACH WIEJSKICH (NA PRZYKŁADZIE PRZYGRANICZA WOJEWÓDZTWA DOLNOŚLĄSKIEGO)
}

\author{
Mateusz Smolarski
}

\section{Passenger rail transport in rural areas (on the example of the borderland of Lower Silesia Voivodship)}

\begin{abstract}
The issues of railway transport functioning on a local and regional scale constitute an important element of the voivodship transport policy. Coordinating passenger transport between various companies and creating a transport offer adequate to the needs becomes a key issue in creating a coherent regional rail system. The aim of the analysis was to determine the role and to identify the rules of functioning of regional rail transport in peripheral areas based on the data on passenger flows. Correlation relationships between the number of passengers and the number of inhabitants as well as the transport offer were investigated. The research area was narrowed down to two NUTS 3 units (Jelenia Góra and Wałbrzych). The demographic potential, i.e. the number of inhabitants of a given town had the greatest impact on the number of passengers in the studied rural areas. The smallest dependence exists between the transport offer and the number of inhabitants. This means that there is no exact adjustment of the number of train pairs to the demographic potential of the town. In addition, transport unevenness (weekday-weekend) in terms of the number of rail connections and passenger flows was examined. Rail transport can be considered as the backbone of the region's transport links and on its basis an integrated system (rail and bus) of communication services for rural areas should be created. The conducted research is an example of empirical analysis based on the data on passenger flows, which, in the Polish realities, are often difficult to access or incomplete.
\end{abstract}

Keywords: peripheral area, rail transport, borderland, transport exclusion, passenger demand, rural transport 
Zarys treści: Problematyka funkcjonowania transportu kolejowego w skali lokalnej i regionalnej stanowi istotny element polityki transportowej województwa. Z kolei kwestia koordynacji przewozów pasażerskich między różnymi spółkami kolejowymi oraz tworzenia atrakcyjnej oferty przewozowej staje się kluczową kwestią w tworzeniu spójnego systemu kolei regionalnej. Celem analizy jest określenie roli i identyfikacja prawidłowości funkcjonowania regionalnego transportu kolejowego na obszarach peryferyjnych na podstawie danych o potokach podróżnych. Ponadto zbadane zostały zależności korelacyjne między liczbą pasażerów a liczbą mieszkańców oraz ofertą przewozową. Obszar badań został zawężony do dwóch jednostek NUTS 3 (jeleniogórski oraz wałbrzyski). Największy wpływ na liczbę pasażerów na badanych terenach wiejskich miał potencjał demograficzny, czyli liczba mieszkańców danej miejscowości. Kolejną zmienną kształtującą wartości analizowanej cechy była ta opisująca ofertę przewozową. Oceniony został związek między ofertą przewozową a liczbą pasażerów. Podkreśla to fakt, że liczba pociągów jest związana ze stosunkowo wysokim stopniem wykorzystania kolei przez mieszkańców. Najmniejsza zależność istnieje między ofertą przewozową a liczbą mieszkańców. Oznacza to, że brak jest ścisłego dostosowania liczby par pociągów do potencjału demograficznego miejscowości. Dodatkowo zbadane zostały nierównomierności (roboczo-weekendowe) przewozowe w zakresie liczby połączeń kolejowych oraz potoków pasażerskich. Transport kolejowy może zostać uznany jako szkielet powiązań komunikacyjnych regionu i na jego podstawie powinien być tworzony zintegrowany system (kolejowo-autobusowy) obsługi komunikacyjnej terenów wiejskich. Przeprowadzone badania stanowią przykład empirycznej analizy na podstawie danych dotyczących potoków pasażerskich, które w polskich realiach są często trudno dostępne albo niepełne.

Stowa kluczowe: obszary peryferyjne, transport kolejowy, pogranicze, wykluczenie komunikacyjne, popyt pasażerski, transport wiejski

\section{Wprowadzenie}

Za przesłankę do podjęcia tematyki można uznać możliwość wykorzystania danych dotyczących liczby pasażerów, które w polskich realiach często są trudne do zdobycia i dalszego wykorzystania w celach naukowych. Problematyka funkcjonowania regionalnego transportu kolejowego w kontekście niespójnej polityki transportowej (Taylor 1997a) staje się interesującym zagadnieniem badawczym. W ostatnich latach zauważalny jest wzrost liczby pasażerów, szczególnie w przewozach kolei regionalnych. W związku z tym zasadna jest analiza funkcjonowania systemu transportowego ${ }^{1}$ z wykorzystaniem danych o potokach pasażerskich. Wartość dodaną może stanowić wykonanie analizy na obszarze peryferyjnym. Przeprowadzone badania mogą wprowadzać elementy rekomendacji w zakresie tworzenia regionalnych systemów transportowych, opartych na kolei oraz autobusach.

\footnotetext{
${ }^{1}$ Analiza systemów transportowych może dotyczyć tylko infrastruktury oraz (szerzej) powiązań komunikacyjnych wynikających z oferty przewozowej. M. Rechłowicz oraz V. Besalov (2011) podkreślali rolę tzw. analizy systemowej uwzględniającej liczbę połączeń transportem publicznym.
} 
Obszar Dolnego Śląska stanowi teren o wysokim stopniu rozwinięcia i gęstości sieci kolejowej. Należy zaznaczyć, że istnieje tutaj zjawisko wygaszania ruchu osobowego (szczególnie po 1989 r.). Problematyka ta została poruszona w opracowaniach monograficznych na temat rozwoju i zaniku sieci kolejowej w Polsce (Koziarski 1993; Taylor 2007). Na badanym obszarze w ruchu pasażerskim funkcjonują dwie spółki przewozowe: Koleje Dolnośląskie oraz Przewozy Regionalne. Koleje Dolnośląskie są spółką podlegającą Urzędowi Marszałkowskiemu Województwa. Przewozy Regionalne jako spółka krajowa została podzielona w zakresie własności na poszczególne województwa w 2008 r. W momencie przejmowania spółki (udziałów) przez Urząd Marszałkowski na województwo dolnośląskie „przypadło” 7,3\% wszystkich udziałów (Taylor, Ciechański 2017).

Polityka transportowa jest związana z rozwojem regionalnym i oddziałuje m.in. na regiony peryferyjne, gdzie polepszenie dostępności transportowej może wpłynąć na lepszy dostęp do regionalnych centrów albo rynków pracy (Nutley 1998; Taylor 1997b, 1999).

\section{Cele badaweze, obszar badań, metody badaweze}

Celem analizy jest określenie roli i identyfikacja prawidłowości funkcjonowania regionalnego transportu kolejowego na obszarach peryferyjnych województwa na podstawie danych o potokach podróżnych.

Dodatkowo postawione zostało pytanie badawcze (ryc. 1): czy i w jakim stopniu potoki pasażerskie są związane z liczbą ludności danej miejscowości (potencjał

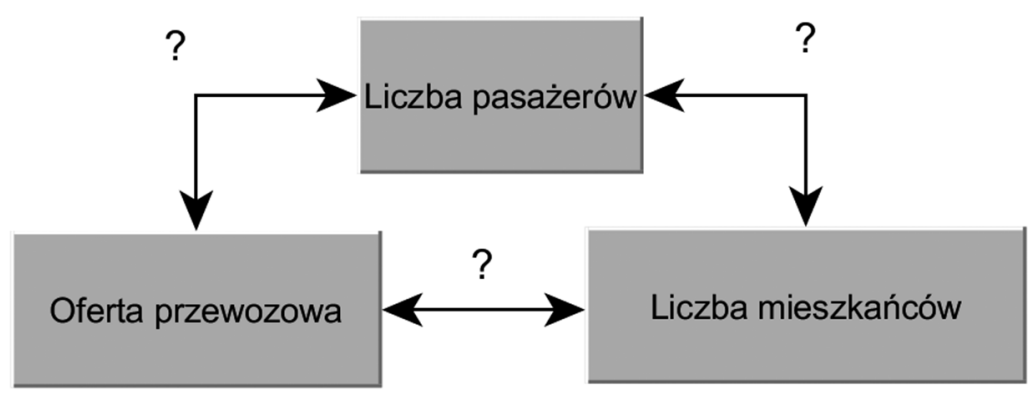

Ryc. 1. Analizowane związki korelacyjne

Fig. 1. Analysed correlation relationships 
demograficzny) oraz ofertą przewozową (w myśl zasady, że duża liczba połączeń kolejowych przekłada się na wysoką liczbę pasażerów)?

Badania zostały przeprowadzone na obszarze przygranicza województwa dolnośląskiego, opartego na NUTS3 (jeleniogórski, wałbrzyski). Jednostką obserwacji był zbiór 55 miejscowości wiejskich² (ryc. 2). Obszar badań został oparty o jednostki NUTS3.

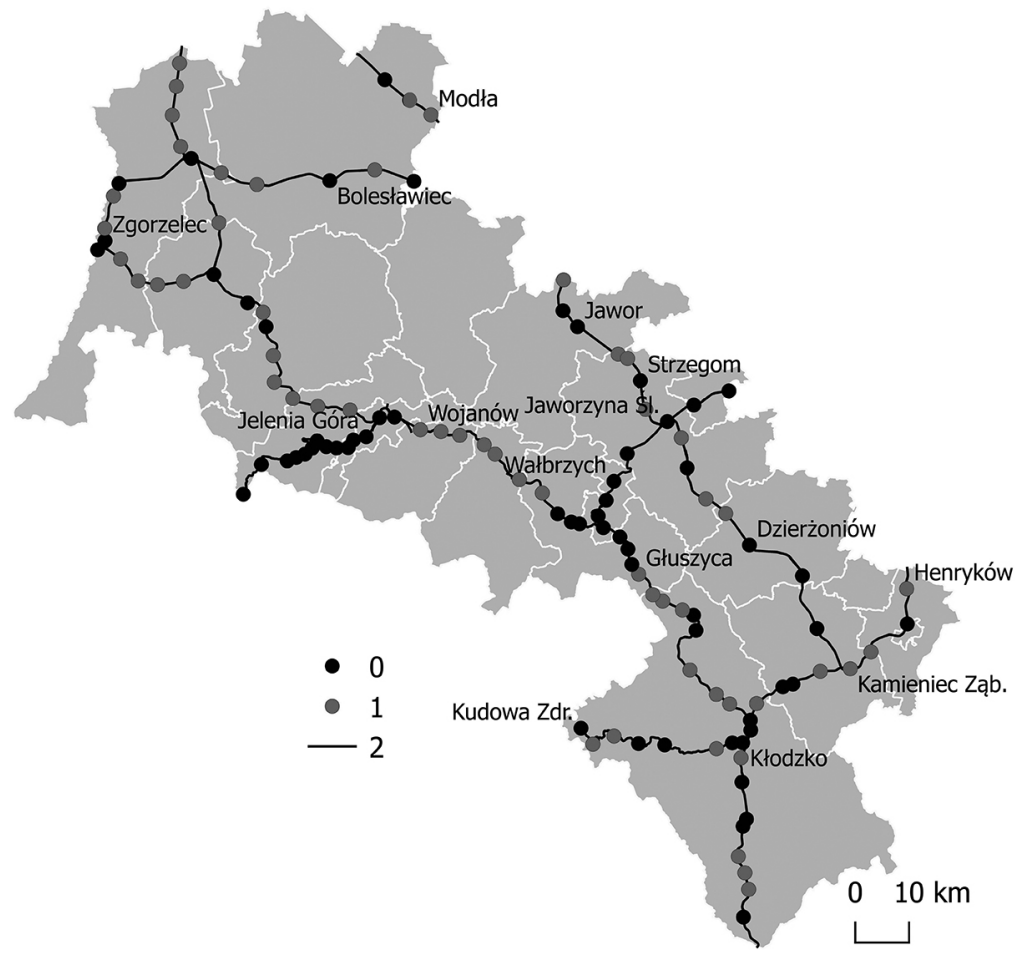

Ryc. 2. Obszar badań

Fig. 2. Area of research

Objaśnienia: 0 - miejscowości nieobjęte badaniem; 1 - analizowane miejscowości; 2 - linie kolejowe. Explanations: 0 - cities not analysed; 1 - analysed cities; 2 - railway lines.

\footnotetext{
${ }^{2}$ We wszystkich prawie przypadkach każda miejscowość była obsługiwana tylko przez jedną stację. Do wyjątków należy Gierałtów.
} 


\section{Metody badawcze}

Wykorzystano dane dotyczące liczby podróżnych oraz rozkładu jazdy połączeń kolejowych za okres 3-9.04.2017 r. (z powodu braku danych z badania wyłączone zostały połączenia pospieszne, ekspresowe ${ }^{3}$ ). Dane dotyczą przewozów regionalnych realizowanych przez Koleje Dolnośląskie oraz Przewozy Regionalne ${ }^{4}$ i zostały pozyskane z Urzędu Marszałkowskiego Województwa Dolnośląskiego. Były to badania realizowane przez spółki przewozowe i polegały na zliczaniu liczby pasażerów korzystających z wszystkich stacji i pociągów. Stanowią one element corocznych pomiarów liczby pasażerów korzystających z regionalnego transportu kolejowego ${ }^{5}$. Liczono pasażerów we wszystkich pociągach regionalnych w danym okresie oraz wszystkich wsiadających na danej stacji.

Analiza dotyczyła stacji kolejowych na terenach wiejskich. W zasadniczej fazie dokonano analizy korelacyjnej oraz zbadano zależności między trzema elementami: ludnością danej miejscowości, na której terenie jest zlokalizowana stacja kolejowa ${ }^{6}$, ofertą przewozową (liczba pociągów odjeżdżających średnio każdego dnia roboczego w okresie 3-9.04.2017) oraz potokami pasażerskimi (pasażerowie odjeżdżający z poszczególnych stacji) w ciągu 5 dni roboczych.

W literaturze przedmiotu (geografii transportu) popularne jest opieranie analiz na danych o potokach podróżnych ${ }^{7}$. Dane o konkretnej liczbie podróżnych, którzy odjeżdżają z danej stacji, mogą być opisywane w dwojaki sposób, jako dane punktowe lub liniowe: [1] faktyczna liczba ludzi odjeżdżających z danej stacji (stacja jest postrzegana jako generator ruchu; w przypadku uwzględnienia również osób

\footnotetext{
${ }^{3}$ Pociągi pospieszne kursowały w badanym okresie jedynie na odcinku Węgliniec-Wrocław oraz (Szklarska Poręba) Jelenia Góra-Wrocław. Dodatkowo, zdaniem Autora, pociągi pospieszne, ekspresowe pełnią inną funkcję niż składy regionalne oraz osobowe. Te pierwsze stanowią raczej element powiązań województwa z krajem, a nie codziennych przemieszczeń. Aspekty związane z podziałem pociągów na poszczególne kategorie zostały poruszane przez Zajferta (2012, 2013, 2015), który dzielił kolejowy transport pasażerski na pociągi regionalne, aglomeracyjne oraz dalekobieżne. Podobny podział został zaproponowany przez Żurkowskiego (2009): regionalne, aglomeracyjne, międzyregionalne, międzyaglomeracyjne. Z kolei Goliszek (2015) wyróżnił ekspresy (kwalifikowane), pospieszne (kwalifikowane), osobowe dalekobieżne (kwalifikowane), osobowe.

${ }^{4}$ Koleje Dolnośląskie są spółką będącą w całości pod zarządem Urzędu Marszałkowskiego Województwa Dolnośląskiego. Rozpoczęły swoją działalność w 2008 r. (o przekształceniach spółek kolejowych oraz nowych przedsiębiorstwach kolejowych, por. Taylor, Ciechański 2017).

${ }^{5}$ Innym sposobem (poza liczeniem bezpośrednim) jest analiza oparta na systemie sprzedaży biletów, m.in. PKP Intercity opiera się na tego typu danych. W niniejszej analizie dane są oparte o obserwacje (pomiar) liczby pasażerów przez obsługę pociągu oraz dodatkowych pracowników (ankieterów).

${ }^{6}$ Należy podkreślić fakt, że zdarzają się przypadki, w których stacja kolejowa jest zlokalizowana bliżej jakiejś miejscowości, niżby to wynikało z nazwy przystanku kolejowego. W takim przypadku stanowi ona raczej „punkt obsługi” miejscowości, która znajduje się bliżej.

${ }^{7}$ Dane o potokach podróżnych nie są zazwyczaj publikowane publicznie. Jeżeli jakieś szczątkowe informacje są podawane, to najczęściej są one stricte opisowe, bez mo:̇liwości empirycznego pogtębienia informacji.
} 
dojeżdżających można by ją nazwać destynatorem), inaczej: daily station passenger volume lub station ridership (Fröidh, Camilla Byström 2013; Pan i in. 2017, s. 53); [2] Station-to-station ridership - przepływy między stacjami (Kepaptsoglou i in. 2016).

Potoki podróżnych można uznać za pochodną ruchliwości, rozumianej jako faktycæne [...] przemieszczenia przestrzenne jednostek (Taylor 1999, s.10). Dane wykorzystane w niniejszej analizie wpisują się zarówno w kontekst badań zagranicznych, jak i zasygnalizowanych przez polskich badaczy geografii transportu.

Badanie dotyczy również nierównomierności w zakresie potoków pasażerskich i oferty przewozowej pomiędzy dniami roboczymi oraz weekendowymi ${ }^{8}$. Zmienność potoków pasażerskich w układzie weekendowym pozwala określić wahania okresowe w ciągu tygodnia oraz ocenić system transportowy (por. Potrykowski, Taylor 1982, s. 32).

\section{Problematyka badaweza}

Kwestia organizacji transportu publicznego pozamiejskiego jest stosunkowo ważna. Taylor (2006) w swoich badaniach odnosił się do społecznych skutków likwidacji linii kolejowych. Zwracał uwagę na problematykę wygaszania popytu na liniach kolejowych oraz dalszych konsekwencji prowadzących do wykluczenia komunikacyjnego danego regionu9. Stanny (2011) podkreśla rolę wykluczenia komunikacyjnego w jednym z zdefiniowanych typów obszarów peryferyjnych.

Bański (2014) zwraca uwagę, że obszary peryferyjne mogą stać się obszarem wykluczenia społecznego, ale z drugiej strony podkreśla, że poprawa dostępności transportowej występuje głównie wokół obszarów metropolitalnych oraz wzdłuż głównych ciągów transportowych (Bański 2014, s. 20). Z kolei R. Rudnicki (2011) wskazuje w swoich badaniach na kwestię peryferii powiatów ziemskich w odniesieniu do różnych aspektów przestrzennych (odległość fizyczna od Warszawy, miasta wojewódzkiego oraz granicy państwa). Jest to podkreślenie roli istnienia peryferiów zewnętrznych, jak i wewnętrznych (Rosik i in. 2017). W swoich badaniach odnosił się do 3 elementów peryferyjności: [1] demograficzno-społecznego, [2] ekonomicznego i [3] ekologicznego. Zidentyfikował zjawisko peryferyjności jako najsilniej determinowane przez położenie danej miejscowości w odniesieniu do stolicy regionu.

Niska dostępność transportowa pogłębia „odcięcie” danych miejscowości i obszarów. Przeprowadzone w warunkach brytyjskich badania wykazały związek między dostępnością transportową a udziałem w życiu społecznym i korzystaniem $z$ aktywności lokalnych (Kenyon i in. 2002; Preston, Rajé 2007). Z kolei Czapiewski (2011) podkreśla

\footnotetext{
${ }^{8}$ Innymi słowy jest to stosunek między liczbą pasażerów (oraz liczbą połączeń) w dzień roboczy i wolny. ${ }^{9}$ Szeroki przegląd literatury i problematyki wykluczenia komunikacyjnego i społecznego został przeprowadzony przez J. Jaroša (2017).
} 
fakt, że lokalizacja i dostępność danego obszaru jest istotnym elementem wpływającym na „sukces” regionu, ale nie może być uznany za jedyny czynnik warunkujący.

Wolański i in. (2016) w swojej analizie skupił się na transporcie publicznym na obszarach położonych poza terenami MOF-ów. Podobnie jak u Taylora (2006) dodatkowym elementem poznawczym były badania ankietowe ludności wiejskiej. Taylor (1997b) dodatkowo w artykule przeglądowym odnosił się do tzw. dostępności osobistej oraz spotecznych aspektów dostepności (Taylor 1997b, s. 265).

Tereny peryferyjne charakteryzują się specyficznymi uwarunkowaniami w zakresie funkcjonowania transportu publicznego (godziny kursowania, frekwencja na niskim poziomie, brak połączeń bezpośrednich oraz skoordynowanych przesiadek, por. Petersen 2016). Nawet obszary zlokalizowane w pozornie dobrej konfiguracji transportowej, np. tuż koło aglomeracji miejskich można określić jako niewydolne komunikacyjne, tzw. car dependent suburban area (Hickman, Banister 2014, s. 141).

Badania Guzika $(2012,2016)$ odnosiły się do analizy wiejskich obszarów Szwajcarii pod względem organizacji transportu publicznego i podkreślały rolę dostępności komunikacyjnej obszarów peryferyjnych (2016) i terenów wiejskich Polski, Słowacji oraz Czech (2012). Dodatkowo podkreślał on rolę deregulacji i przekształceń rynku kolejowego, co skutkowało marginalizacją kolei w skali lokalnej oraz regionalnej (Guzik 2012).

W polskich warunkach badawczych, przy braku pełnego dostępu do danych, duża część badań opiera się na analizie strony podażowej (oferty przewozowej itp.) oraz organizacyjnej. Wydaje się, że istnieje możliwość wykorzystania tego typu danych do identyfikacji generatorów ruchu, wahań dobowych oraz tygodniowych przemieszczeń pasażerskich. Chaberko (2010) oceniał funkcjonowanie kolei w dużych miastach, ale tylko w oparciu o ofertę przewozową i rozwiązania organizacyjne. Kretowicz (2010) analizował połączenia autobusowe na peryferiach województwa małopolskiego. Odnosił się również do ewentualnej koordynacji systemów autobusowych.

Dej (2010) przeprowadziła analizę funkcjonowania transportu w kontekście dojazdów do pracy na 5 przykładowych obszarach peryferyjnych Polski na podstawie badań ankietowych. Zidentyfikowała brak związku między potrzebami pracowników na terenach peryferyjnych a ofertą lokalnych przewoźników autobusowych. W warunkach wolnorynkowych ewentualny potok pasażerski jest zbyt mało opłacalny dla lokalnego przewoźnika. Pytaniem otwartym pozostaje kwestia: na ile te badania mogłyby być jeszcze bardziej kompleksowe, jeśliby objęły również kwestie popytu pasażerskiego.

W polskich analizach istnieje niedobór empirycznych badań związanych z elementem popytowym w transporcie publicznym. Często są to dane objęte tajemnicą handlową lub bardzo trudno dostępne. Na problematykę, w kontekście braku spójności przedmiotowej oraz czasowej, dostępu do danych publicznych związanych z funkcjonowaniem transportu publicznego zwraca również uwagę Wolański wraz 
z zespołem (2016). Brak ujednoliconej bazy danych autobusowego transportu publicznego został zasygnalizowany w badaniach Rosika i in. (2017).

Wiśniewski (2015), badając dostępność miast województwa łódzkiego, odniósł się wprost do transportu kolejowego i zaznaczył, że wielkośc i struktura przewozów nie mogty zostać zbadane ze względu na brak danych (Wiśniewski 2015, s. 27). W dalszej części artykułu wykazane zostaną możliwości wykorzystania tego typu danych. Mogą to być informacje pozyskiwane z systemów sprzedaży lub z podsystemów dystrybucji biletów, np. dane pozyskane z logowania kart do bramek biletowych (Pan i in. 2017). Jednym z przykładów wykorzystania danych o potokach podróżnych są badania przeprowadzone dla systemu transportu kolejowego w Szwecji. Fröidh i Byström (2013) wykorzystali je do oceny współistnienia różnych systemów organizacji transportu kolejowego w oparciu o wskaźnik obsługi (level of service).

W zagranicznej literaturze mocno podkreślana jest rola ewentualnego wykluczenia komunikacyjnego. Co ważne, dostępność transportowa jest badana w wielu aspektach, np. jako problematyka przemieszczeń i mobilności osób starszych na terenach wiejskich Szkocji, gdzie na podstawie badań ankietowych analizowano zjawisko wykluczenia komunikacyjnego, tzw. transport-related social exclusion, por. Shergold, Parkhurst 2012.

Doświadczenia krajów niemieckojęzycznych, m.in. Szwajcarii, wskazują, że rozwój zintegrowanych systemów transportowych wpływa na wzrost popytu na transport publiczny (Buehler, Pucher 2012). Podobny wzrost zainteresowania transportem publicznym zidentyfikowany został w Czechach (Štastná i in. 2015).

W przypadku lokalizacji stacji kolejowej należy podkreślić, że w dużych ośrodkach miejskich zidentyfikowano zależność, w myśl której im dalej od centrum miasta oraz zabudowań jest położona konkretna stacja, tym mniejsze potoki podróżnych. W przypadku obszarów wiejskich tolerancja pasażera na dojazd do stacji jest większa. Związek zabudowy mieszkaniowej oraz lokalizacji stacji kolejowej na obszarach wiejskich położonych w pobliżu Wrocławia badał Jurkowski (2017). Dodatkowo ten sam Autor odnosił się również do zintegrowanych węzłów przesiadkowych w strefach podmiejskich największych aglomeracji (Jurkowski 2016).

Prowadzenie polityki transportowej w regionie powinno opierać się na powiązaniu transportu kolejowego oraz autobusowego. Dobre praktyki są stosowane w tym zakresie w Czechach, Szwajcarii, Niemczech. Guzik (2016) zidentyfikował funkcjonowanie autobusów na telefon w Szwajcarii, które kursują po telefonicznym zgłoszeniu zapotrzebowania na przewóz.

Procesy zawieszania ruchu osobowego są szczególnie intensywne na liniach lokalnych. Należy zaznaczyć, że tego typu trasy są zlokalizowane zarówno na badanym obszarze, jak i w Czechach. Taczanowski (2012) w swoich badaniach zidentyfikował istotne różnice w zakresie intensywności zamykania lokalnych tras kolejowych w Polsce i Czechach. Według jego analizy w Polsce między 1989 a 2011 r. 
zlikwidowano $90 \%$ linii kolejowych trzeciej kategorii oraz $44 \%$ tras drugiej kategorii. W Czechach w analogicznym czasie zawieszono ruch na $14 \%$ lokalnych tras.

\section{Wyniki badań}

\section{Generatory ruchu w transporcie kolejowym w ujęciu przestrzennym}

Liczba pasażerów na poszczególnych stacjach (ryc. 3) wykazuje zróżnicowanie przestrzenne. Potoki pasażerskie o najwyższym natężeniu występują na odcinkach:

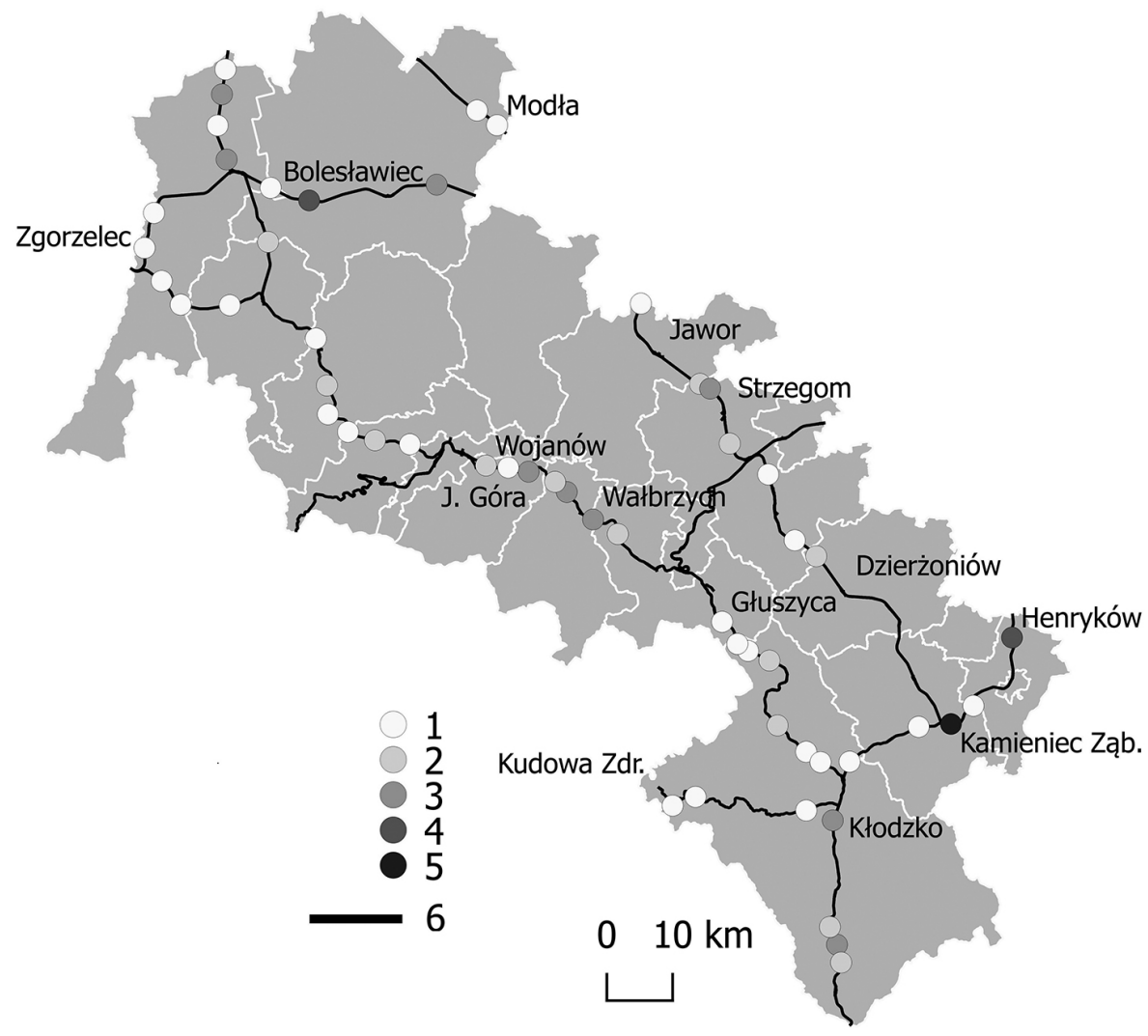

Ryc. 3. Liczba pasażerów kolejowych w ciągu 5 dni roboczych

Fig. 3. Number of rail passengers during 5 weekdays

Objaśnienia: 1 - 1-51; 2 - 52-106; 3 - 107-217; 4-218-532; 5 - 533-816; 6 - linie kolejowe.

Explanations: 1 - 1-51; 2 - 52-106; 3 - 107-217; 4-218-532; 5 - 533-816; 6 - railway lines. 
Jelenia Góra-Wałbrzych, Kłodzko-Międzylesie oraz Węgliniec-Zagajnik. Wpływ na to mogą mieć: wysokie prędkości handlowe (szczególnie na trasie z Węglińca), brak silnej konkurencji autobusowej (Jelenia Góra-Wałbrzych) oraz słabo rozwinięta siatka połączeń autobusowych i atrakcyjny rozkład jazdy na kolei (Kłodzko-Międzylesie).

Największą liczbą połączeń charakteryzują się stacje (przystanki) zlokalizowane na liniach: Węgliniec-Zagajnik ${ }^{10}$, Wałbrzych-Jelenia Góra oraz Kamieniec Ząbkowicki-Kłodzko. Najsłabiej rozwinięta oferta przewozowa występuje na odcinkach: Węgliniec-Zgorzelec oraz Węgliniec-granica województwa. Na dwóch niezelektryfikowanych trasach (Kudowa-Kłodzko oraz Kłodzko-Wałbrzych) liczba połączeń nie przekracza 10 dziennie. Na 25\% badanych stacji liczba pociągów w ciągu dnia to 14 połączeń. Ofertę przewozową należy ocenić jako stosunkowo dobrą, na większości tras liczba pociągów wynosi co najmniej 16 połączeń dziennie.

Odcinki o największych potokach podróżnych oraz z najlepszą ofertą przewozową ${ }^{11}$ pokrywają się. Już wstępna analiza wykazuje więc związek między liczbą pasażerów a odpowiednim rozkładem jazdy. Inne czynniki pośrednio determinujące ten związek to m.in.: stan techniczny linii, maksymalne prędkości szlakowe, elektryfikacja szlaku.

\section{Analiza korelacji}

Analiza korelacji ${ }^{12}$ dotyczyła trzech aspektów (ryc. 4):

- liczby ludności w danej miejscowości ${ }^{13}$ (dane GUS - Narodowy Spis Ludności 2011),

- oferty przewozowej (średnia liczba odjeżdżających pociągów w ciągu jednego dnia),

- liczby pasażerów (liczba pasażerów wsiadających w ciągu jednego tygodnia roboczego).

\footnotetext{
${ }^{10}$ Odcinek ten stanowi część międzynarodowego korytarza transportowego i jest przystosowany do jazdy z prędkością $160 \mathrm{~km} / \mathrm{h}$.

${ }^{11}$ Należy zaznaczyć, że oferta przewozowa jest tylko jednym z aspektów wpływających na atrakcyjność. Do pozostałych można zaliczyć: komfort, częstotliwość, bezpieczeństwo podróży, kwalifikacje personelu (van Lierop i in. 2018).

${ }^{12}$ Analiza korelacji liniowej na podstawie współczynnika Pearsona została przeprowadzona w oparciu o oprogramowanie SPSS. Wszystkie analizowane wartości tego wskaźnika okazały się być istotne statystycznie na poziomie 0,01 .

${ }^{13}$ Co prawda zasięg punktu jest zazwyczaj rozciągnięty poza macierzystą miejscowość, ale Autor przyjął założenie, że z transportu kolejowego korzystają tylko mieszkańcy danej jednostki osadniczej. Odniesienie się do liczby ludności spoza miejscowości wymagałoby ewentualnych odrębnych badań dostępności. Rosik i in. (2017) zaznaczyli, że wośrodkach o mniejszej randze [...] z transportu kolejowego korzystajq mieszkańcy terenów zlokalizowanych w bliskim sasiedztwie stacji (Rosik i in.2017, s.269).
} 


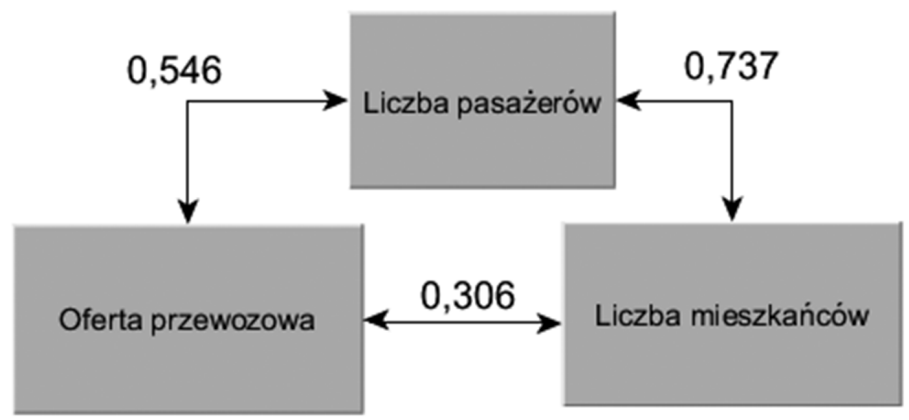

Ryc. 4. Związki korelacyjne

Fig. 4. Correlation indicators

Pomiędzy liczbą ludności a ofertą połączeń kolejowych istnieje średni związek, który obrazuje wartość współczynnika korelacji liniowej wynosząca 0,306. W teoretycznym ujęciu można założyć, że większe ośrodki (pod względem liczby ludności) powinny mieć zagwarantowaną większą liczbę połączeń. Omawiana korelacja jest najniższa ze wszystkich analizowanych. Na terenach peryferyjnych położonych z dala od dużych aglomeracji miejskich oferta przewozowa kształtuje się na stosunkowo dobrym poziomie. W zbiorze wszystkich badanych miejscowości minimalna liczba połączeń kolejowych wynosi 7 dziennie, a maksymalna 35 połączeń. W większości badanych jednostek liczba połączeń kolejowych występuje na poziomie $14 \mathrm{w}$ ciągu dnia. W 7,1\% badanych miejscowości jest poniżej 10 kursów dziennie ${ }^{14}$.

W przypadku transportu kolejowego oferta przewozowa jest w praktyce tworzona dla całych odcinków linii. Stosunkowo mało jest sytuacji, w których pociąg osobowy (regionalny) nie zatrzymuje się na wszystkich przystankach. Na odcinkach głównych magistrali (np. Wrocław- Jelenia Góra; Wrocław-Zgorzelec) prędkości pociągów są z reguły wyższe niż na liniach bocznych, co przekłada się na lepszą ofertę przewozową. Brak korelacji między liczbą ludności a liczbą pasażerów może skutkować nadwyżką oferty przewozowej lub brakiem popytu na usługi transportowe. Ewentualnym rozwiązaniem byłoby wprowadzenie pociągów przyspieszonych lub, na wzór czeskich kolei, przystanków na żądanie.

Największa badana miejscowość - Kamieniec Ząbkowicki - jest obsługiwana przez 35 połączeń kolejowych dziennie. Stacje położone na głównych trasach

\footnotetext{
${ }^{14}$ Liczba połączeń poniżej 7 par połączeń może być uznawana za niedostateczną ofertę przewozową (Majewski 2006). Finansowanie oferty przewozowej na poziomie 6 par na dobę stanowi niepotrzebną rozrzutność finansową (Taylor, Ciechański 2017, s. 234).
} 
z reguły obsługiwane są przez większą liczbę kursów kolejowych (Tomaszów Bolesławiecki, 28 połączeń). Należy jednak podkreślić fakt, że istotnym elementem jest stan techniczny linii kolejowej oraz jej możliwości techniczne (np. elektryfikacja, liczba torów itp.). Jedna z największych badanych miejscowości, zlokalizowana na niezelektryfikowanej linii (Ruszów - 1818 mieszkańców), jest obsługiwana przez 7 połączeń dziennie.

Zdecydowanie silniejsze związki korelacyjne zostały wykazane pomiędzy liczbą mieszkańców a liczbą pasażerów korzystających ze stacji. Korelacja wyniosła 0,737. Świadczy to o wysokim związku między potencjałem demograficznym a rzeczywistymi potokami pasażerskimi. Maksymalna liczba podróżnych (816) wystąpiła w Kamieńcu Ząbkowickim. Kolejne pod względem liczby pasażerów to Zebrzydowa oraz Henryków. Należy zaznaczyć, że miejscowości, na których odnotowany jest największy ruch pasażerski, są położone na linii magistralnej Wrocław-Kłodzko-Międzylesie.

Generalnie rzecz biorąc, potoki podróżnych na analizowanym obszarze należy ocenić jako bardzo niskie. Na większości stacji w ciągu jednego dnia roboczego średnio wsiadało około 4 osoby dziennie. $Z$ kolei na połowie stacji ruch nie przekraczał 9 osób dziennie. Jeżeli odnieść wartości do średniodobowego potoku ruchu, to z $54 \%$ badanych stacji korzysta mniej niż 10 pasażerów dziennie, z $80 \%$ mniej niż 26 osób. Największe wartości zidentyfikowano w Kamieńcu Ząbkowickim (163 osoby dziennie), Zebrzydowej (106) oraz Henrykowie (62).

Można przyjąć, że większe (pod względem liczby ludności) jednostki osadnicze generują duże potoki podróżnych, podkreślając jednak, że istnieją jednostki, które nie są potwierdzeniem powyższej (teoretycznej) zależności. Są miejscowości, które mimo wysokiego potencjału demograficznego (liczby ludności) nie generują dużego ruchu pasażerskiego (np. Głuszyca Górna - 17 pasażerów, 1059 mieszkańców; Ubocze - 37 pasażerów, 1265 mieszkańców). Druga grupa to miejscowości z dużą liczbą pasażerów, a jednocześnie małą liczbą ludności (Sędzisław - 217 pasażerów, 658 mieszkańców; Ciechanowice - 106 pasażerów, 987 mieszkańców).

Pomiędzy liczbą pasażerów a ofertą przewozową istnieje średni związek, który obrazuje wartość współczynnika korelacji liniowej wynosząca 0,546. Świadczy to o silnym związku i pozwala podkreślić istotny wpływ oferty przewozowej na tworzenie atrakcyjnego rynku usług transportu publicznego. Liczba połączeń oraz odpowiedni rozkład jazdy stanowią bardzo silny czynnik oddziałujący na postrzeganie atrakcyjności lokalnego transportu publicznego (Dea van Lierop i in. 2018). Wspomniany wcześniej niedostatecznie rozwinięty rozkład jazdy, na poziomie 6-7 par dziennie, niewątpliwie może stanowić przyczynę zawieszania ruchu osobowego. Nawet na aktualnym poziomie liczby połączeń istotny związek korelacyjny świadczy o tym, że lokalna społeczność wykorzystuje transport kolejowy. Tym ciekawsze mogą być ewentualne odtworzenia siatki połączeń i poprawa jej funkcjonowania. 
Cechy wpływające na liczbę pasażerów można podzielić na dwie grupy: zewnętrzne (rozwój społeczno-gospodarczy regionu, zagospodarowanie terenu, stopień urbanizacji, liczba podmiotów gospodarczych itd.) lub wewnętrzne, czyli zależne od przewoźnika kolejowego (Pan i in. 2017). Wskaźniki zewnętrzne uznawane są za istotniejsze od wewnętrznych. Na badanym obszarze rola oferty przewozowej jest stosunkowo istotna, ale mniej ważna niż czynniki zewnętrzne (liczba mieszkańców).

\section{Nierównomierności w zakresie liczby połączeń oraz potoków pasażerskich}

Nierównomierność przewozowa ${ }^{15}$ w zakresie oferty przewozowej kolejowej świadczy o tym, że kolej podtrzymuje układ komunikacyjny regionu również w okresie weekendowo-świątecznym. Oferta przewozowa jest na podobnym poziomie w dzień roboczy oraz wolny. Średnia wartość wskaźnika dla całego analizowanego zbioru wynosi 96,95\%. 11 miejscowości miało wskaźnik mniejszy niż 90\%. Pozostałe stacje z najbardziej ograniczoną ofertą przewozową w dni wolne były zlokalizowane na ciągu komunikacyjnym Wałbrzych-Jelenia Góra-Szklarska Poręba (m.in. Trzcińsko, Wojanów). Żadna z analizowanych stacji nie była obsługiwana w dni wolne większą liczbą połączeń niż w dni robocze. Stałość oferty przewozowej w transporcie kolejowym w ciągu całego tygodnia, bez wahań w dni wolne, wpływa na postrzeganie kolei pasażerskiej jako stabilnego środka transportu. Nutley (2003) podkreślał rolę łatwych przemieszczeń bez względu na dzień tygodnia oraz porę dnia ${ }^{16}$.

Nierównomierności w zakresie potoków podróżnych z kolei świadczą o zmiennej liczbie pasażerów w ujęciu tygodniowym ${ }^{17}$. Na 26 analizowanych stacjach została zidentyfikowana nadwyżka przemieszczeń, które odbywały się w dzień wolny. $\mathrm{Na}$ pozostałych większy ruch był w dni robocze. Średnia wartość analizowanego wskaźnika dla całego zbioru to $172 \%$, co oznacza blisko dwukrotną przewagę ruchu $\mathrm{w}$ dni robocze nad ruchem weekendowym. $Z$ kolei mediana wyniosła 102\%. Zidentyfikowane wahania w zakresie przewozów pasażerów w ujęciu tygodniowym mogą świadczyć o potrzebie utrzymywania transportu kolejowego nie tylko w dni robocze, ale również w weekend ${ }^{18}$.

\footnotetext{
${ }^{15}$ Wskaźnik nierównomierności przewozowej był ilorazem średnio dziennej oferty przewozowej w dzień roboczy w stosunku do średnio dziennej oferty w dzień wolny. Wartości powyżej $100 \%$ oznaczały większą liczbę połączeń w dzień roboczy.

${ }^{16}$ Mobilność codzienna jest związana z tzw. codziennymi, wahadłowymi przemieszczeniami, tzw. routine travels (Nutley 2003).

${ }^{17}$ Wskaźnik nierównomierności popytowej był ilorazem średnio dziennego potoku pasażerskiego w dzień roboczy w stosunku do średnio dziennego potoku pasażerskiego w dzień wolny. Wartości powyżej 100\% oznaczały większe potoki podróżnych w dzień roboczy.

${ }^{18}$ Jest to szczególnie istotne w przypadku lokalnych przewoźników autobusowych (PKS, bus).
} 


\section{Wnioski i podsumowanie}

Wyniki analizy podkreśliły istotną rolę potencjału demograficznego danej miejscowości w aspekcie korzystania mieszkańców z regionalnego transportu kolejowego. Związek między liczbą mieszkańców a liczbą pasażerów z danej stacji wynosił 0,737. Nie została zidentyfikowana istotna różnica między udziałem ludności w wieku produkcyjnym a potokami podróżnych. Może to być spowodowane małą liczbą mieszkańców w poszczególnych badanych miejscowościach. Jest to potwierdzenie podejścia stosowanego w Europie Zachodniej, które uznaje czynniki zewnętrze (związane z rozwojem społeczno-ekonomicznym regionu) jako ważniejsze od wewnętrznych.

Pomiędzy liczbą pasażerów a ofertą przewozową istnieje średni związek, który obrazuje wartość współczynnika korelacji liniowej wynosząca 0,546. Podobne zależności zostały zidentyfikowane przez Štastná i Vaishara (2017) na terenach wiejskich w Czechach. Jest to podkreślenie istotnej roli atrakcyjnego rozkładu jazdy jako elementu podnoszącego atrakcyjność transportu publicznego.

Mimo przeprowadzonych w poprzednich latach zawieszeń w ruchu kolejowym oraz zmian na regionalnym rynku usług kolejowych transport kolejowy można postrzegać jako istotny element systemu transportowego na obszarach wiejskich oraz peryferyjnych.

Zidentyfikowany w badaniu pogranicza Dolnego Śląska niski wskaźnik nieregularności oferty przewozowej w transporcie kolejowym świadczy o istotnej roli kolejowych przewozów regionalnych. Mogą one być uznane za swoistego rodzaju szkielet regionu komunikacyjnego oraz gwarantować dostęp do transportu publicznego również w dni wolne (Guzik 2016). Jest to jeden z elementów, który zapobiega ewentualnemu wykluczeniu komunikacyjnemu obszarów peryferyjnych. Lucas (2012) podkreśla rolę planowania transportu na lokalnym poziomie i dążenie do prowadzenia zrównoważonej polityki transportowej. Štastná i in. (2015) w badaniach systemów zintegrowanego transportu podkreślali, że mobilność mieszkańców wynika z odmiennych potrzeb, które mogą zaistnieć w różnym czasie i zasięgu przestrzennym. Stabilna oferta przewozowa pozwala na realizację przemieszczeń w różnym czasie, co zostało podkreślone w niniejszej analizie.

Do najważniejszych cech transportu kolejowego na badanym obszarze należy zaliczyć:

- duże zróżnicowanie poszczególnych stacji oraz odcinków międzywęzłowych pod kątem oferty przewozowej, ale z zachowaniem jej na odpowiednio wysokim poziomie (w zakresie liczby połączeń);

- stabilność transportu kolejowego w zakresie oferty przewozowej w ujęciu tygodniowym, z jednoczesnym istotnym zróżnicowaniem w zakresie potoków podróżnych (porównując dzień roboczy oraz wolny); 
- funkcjonowanie dużej liczby stacji, na których wymiana pasażerska jest praktycznie zerowa. Na $50 \%$ analizowanych stacji w jeden dzień roboczy odjeżdża mniej niż 8 pasażerów.

Transport kolejowy na terenach peryferyjnych może być wykorzystywany na najwyższym oraz średnim poziomie powiązań komunikacyjnych. Smolarski (2017) zidentyfikował lepsze powiązania między stolicami gmin z wykorzystaniem transportu kolejowego w Czechach niż w Polsce (dla południowego obszaru pogranicza polsko-czeskiego) i rozwiązania zastosowane w Czechach mogą być implementowane w Polsce. Z kolei połączenia dalekobieżne stanowią element powiązań zewnętrznych regionu, natomiast regionalny transport kolejowy stanowiłby podstawę powiązań lokalnych (ryc. 5). Punktem zbiorczym dla różnych gałęzi transportu powinny być centra przesiadkowe, które redystrybuowałyby ruch pasażerski do poziomu poszczególnych miejscowości.

Między transportem autobusowym a kolejowym nie należy tworzyć sztucznej konkurencji, ale dążyć do komplementarności systemu (ryc. 6) w ramach wzajemnych uzupełnień. Linie autobusowe powinny stanowić uzupełnienie systemu, a nie powielać sztucznie przebieg linii kolejowej (Štastná, Vaishar 2017). Postrzeganie kolei jako szkieletu komunikacyjnego powinno przejawiać się funkcjonowaniem linii kolejowej będącej zwornikiem całego systemu wraz z autobusowymi liniami dowozowymi (feeder bus). Wprowadzenie systemu autobusów dowozowych mogłoby być oparte na elastycznych formach transportu (Štastná i in. 2015).
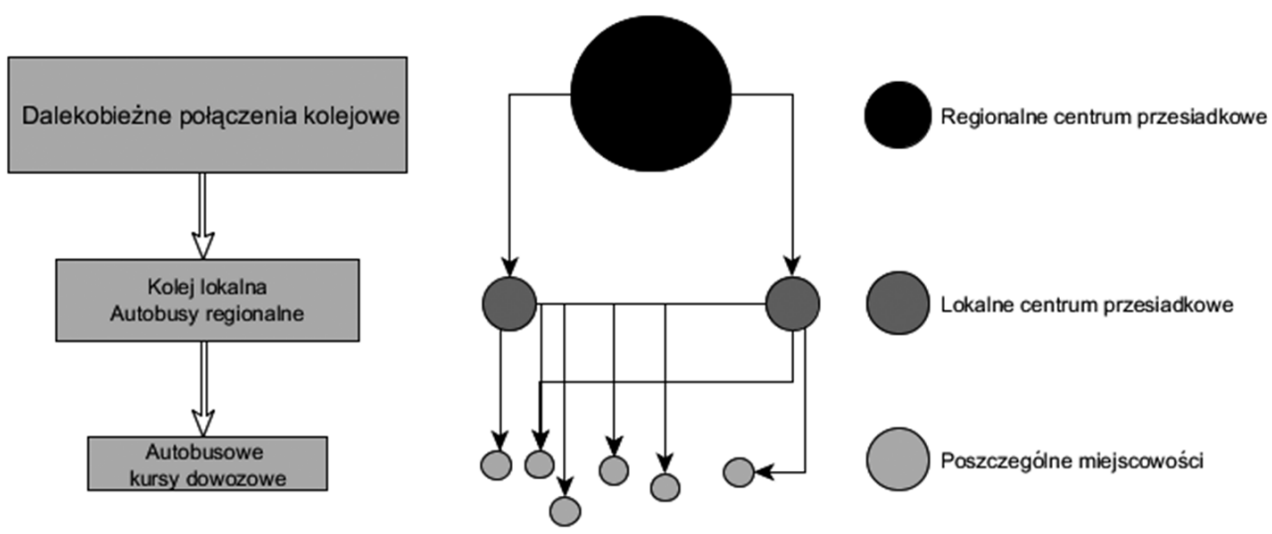

Ryc. 5. Schemat powiązań kolejowo-autobusowych w regionie (proponowany)

Fig. 5. Scheme of railway-bus associations in the region (proposed) 
Wysoki potencjał transportu kolejowego, gęsta sieć kolejowa, stabilna oferta przewozowa winny stanowić punkt wyjściowy do tworzenia Dolnośląskiego Systemu Zintegrowanego Transportu Publicznego. Przeprowadzona analiza stanowi przyczynek do dalszych analiz oraz ewentualnych zastosowań praktycznych.

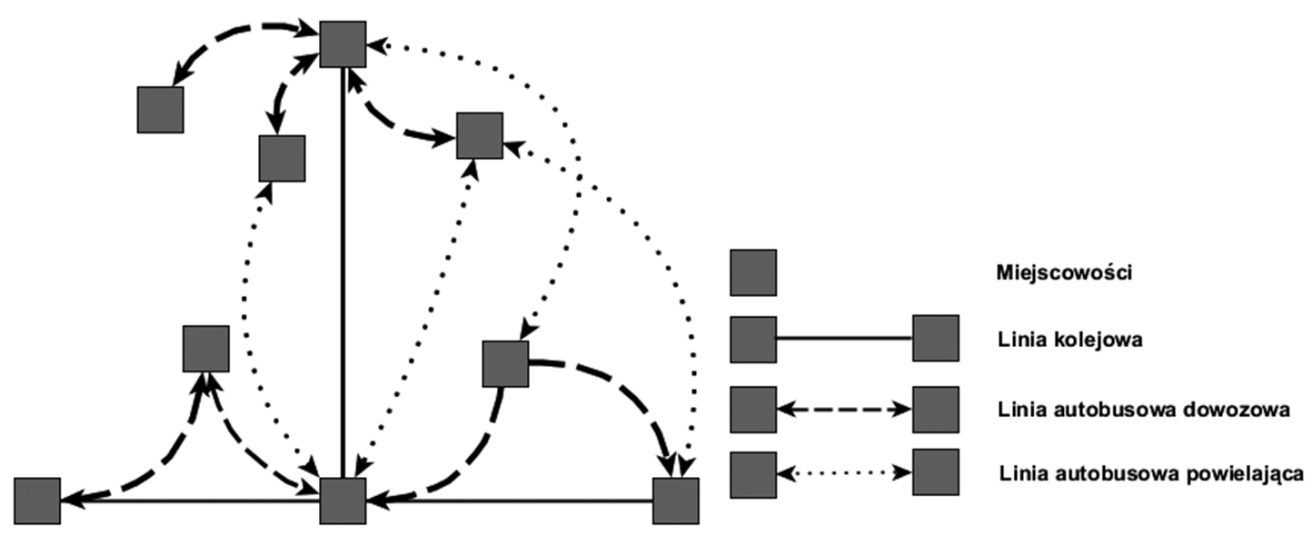

Ryc. 6. Obsługa komunikacyjna wzdłuż linii kolejowej

Fig. 6. Communication service along the railway line

\section{Literatura:}

Bański J., 2014, Perspektywy rozwoju polskiej wsi - wybrane zagadnienia, Wieś i Rolnictwo, 4, $165,13-25$.

Buehler R., Pucher J., 2012, Demand for public transport in Germany and the USA: an analysis of rider characteristics, Transport Reviews 32,5, 541-567.

Chaberko T., 2010, Potencjat kolei jako miejskiego i podmiejskiego środka transportu w wybranych aglomeracjach Europy Środkowo-Wschodniej, Prace Geograficzne, 24, 59-71.

Czapiewski K., 2011, Location matters - analiza zalešności pomiędzy dostępnościq przestrzennq

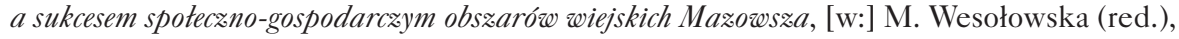
Wiejskie obszary peryferyjne - uwarunkowania i czynniki lokalizacji, 57-73.

Dej M., 2010. Transport publicwny w wiejskich obszarach peryferyjnych Polski i jego dostosowanie do potrzeb lokalnych rynków pracy, Prace Geograficzne, 124, 111-129.

Fröidh O., Byström C., 2013, Competition on the tracks - Passengers' response to deregulation of interregional rail services, Transportation Research Part A, 56, 1-10.

Goliszek S., 2015, Præeja dy koleja po Polsce w 2011 r. - porównanie wedtug kategorii pociagów, Przegląd Komunikacyjny 1, 25-28. 
Guzik R., 2016, Transport publiczny a dostępnośćna obszarach wiejskich Szwajcarii, Prace Komisji Geografii Komunikacji PTG, 19, 4, 49-61.

Guzik R., 2012, Porównanie dostępności w obszarach wiejskich Karpat Polski, Stowacji i Republiki Cizeskiej, [w:] P. Rosik, R. Wiśniewski (red.), Dostępność i mobilność w przestrzeni, IGiPZ PAN, Warszawa, 103-110.

Hickman R., Banister D., 2014, Transport, climate change and the city, Routledge.

Jaroš V., 2017, Social and transport exclusion, Geographia Polonica, 90, 3, 247-263.

Jurkowski W., 2016, Stacje kolejowe w strefach podmiejskich jako zintegrowane węzty przesiadkowe. Analiza porównawcza Krakowa, Łodzi, Poznania $i$ Wroctawia, Problemy Rozwoju Miast, 4, $53-63$.

Jurkowski W., 2017, Ocena integracji zabudowy mieszkaniowej z infrastrukturq kolejowq w obszarach wiejskich w strefie podmiejskiej Wroctawia, Prace Komisji Geografii Komunikacji PTG, 20, 2, 31-42.

Kenyon S., 2011,Transport and social exclusion: access to higher education in the UK policy context, Journal of Transport Geography, 19, 763-771.

Kepaptsoglou K., Stathopoulos A., Karlaftis M., 2017, Ridership estimation of a new LRT system: Direct demand model approach, Journal of Transport Geography, 58, 146-156.

Koziarski S.,1993, Sieć kolejowa Polski w latach 1918-1992, Państwowy Instytut Naukowy, Opole.

Kretowicz P., 2010, Komunikacja lokalna w obszarach peryferyjnych wojewódætwa matopolskiego w dobie przemian rynku przewozów autobusowych, Prace Geograficzne, 124, 131-146.

Lierop v. L, Badami G.M., El-Geneidy M.A., 2018, What influences satisfaction and loyalty in public transport? A review of the literature, Transport Reviews, 38, 1, 52-72.

Lucas K., 2012, Transport and social exclusion: Where are we now?? Transport Policy, 20, 105-113.

Majewski J., 2006, Koleje regionalne w nowych warunkach spotec no-ekonomicænych w świetle badan potoków podró:nych, Prace Komisji Geografii Komunikacji PTG, 20, 2, 31-42.

Nutley S., 1998, Rural areas: The accessibility problem, [w:] B.,Hoyle, R.D. Knowles (red.), Modern transport geography, John Wilet \& Sons, Michigan, 185-215.

Nutley S., 2003, Indicators of transport and accessibility problems in rural Australia, Journal of Transport Geography, 11, 1, 55-71.

Pan X., Li J., Shen Q., Shi C., 2017, What determines rail transit passenger volume? Implications for transit oriented development planning, Transportation Research Part D, 57, 52-63.

Petersen T., 2016, Watching the Swiss: A network approach to rural and exurban public transport, Journal of Transport Geography, 52, 175-185.

Potrykowski M., Taylor Z., 1982, Geografia transportu: :arys problemów, modeli i metod badawczych, PWN, Warszawa.

Preston J., Rajé F., 2007, Accessibiliy, mobility and transport related-exclusion, Journal of Transport Geography, 15, 151-160.

Rechłowicz M., Bespalov V., 2011, Kolej regionalna jako element systemu komunikacyjnego konurbacji, Technika Transportu Szynowego, 18, 5-6, 27-36. 
Rosik P., Pomianowski W., Goliszek S., Stępniak M., Kowalczyk K., Guzik R., Kołoś A., Komornicki T., 2017, Multimodalna dostępność transportem publicznym gmin w Polsce (MULTIMODACC), IGiPZ PAN, Warszawa.

Rudnicki R., 2011, Peryferyjność położenia geograficzno-komunikacyjnego a wybrane wskazniki rozwoju powiatów ziemskich, [w:] M. Wesołowska (red.), Wiejskie obszary peryferyjne - wwarunkowania i czynniki lokalizacji, 35-57.

Shergold I., Parkhurt G., 2012, Transport-related social exclusion among older people in rural Southwest England and Wales, Journal of Rural Studies, 28, 412-421.

Smolarski M., 2017, Transport kolejowy w obstudze gmin we wschodniej čessci pogranicæa polsko-czeskiego, Prace Komisji Geografii Komunikacji PTG, 20, 10, 78-90.

Stanny M., 2011, Typologia wiejskich obszarów peryferyjnych pod waględem anatomii struktury spoteczno-gospodarczej, Wieś i Rolnictwo, 2, 151, 59-75.

Štastná M., Vaishar A., 2017, The relationship between public transport and the progressive development of rural areas, Land Use Policy, 67, 107-114.

Štastná M., Vaishar A., Stonawská K., 2015, Integrated transport system of the South-Moravian Region and its impact on rural development, Transportation Research Part D, 36, 53-64.

Taczanowski J., 2012, A comparative study of local railway networks in Poland and the Ciech Republic, Bulletin of Geography, Socio-economic series, 18, 125-138.

Taylor Z., 1997a, Polska polityka transportowa: jaka jest, a jaka być powinna?, Prace Komisji Geografii Komunikacji PTG, t. III.

Taylor Z., 1997b, Dostępność miejsc pracy, nauki i ustug w obszarach wiejskich jako przedmiot badań geografii spoteczno-ekonomicznej - próba analizy krytycznej, Przegląd Geograficzny, 3, 69, 261-283.

Taylor Z., 1999, Præestræenna dostępność miejsc zatrudnienia, ksætatcenia i ustug a codæienna ruchliwość ludności wiejskiej, Continuo, Wrocław.

Taylor Z., 2006, Railway closures to passenger traffic in Poland and their social consequences, Journal of Transport Geography, 14, 135-151.

Taylor Z., 2007, Rowwój i regres sieci kolejowej w Polsce, IGiPZ PAN, Warszawa.

Taylor Z., Ciechański A., 2017, Deregulacja i przeksztatcenia wtasnościowe przedsiębiorstw transportu lqdowego w Polsce na tle polityki spójności UE, IGiPZ PAN, Warszawa.

Wiśniewski S., 2015, Powiqzania miast województwa tódækiego w systemie kolejowego transportu zbiorowego w świetle potencjatu komunikacyjnego, Prace Geograficzne, 140, 25-38.

Wolański M., Paprocki W., Mazur B., Soczówka A., Jakubowski B., 2016, Publiczny transport

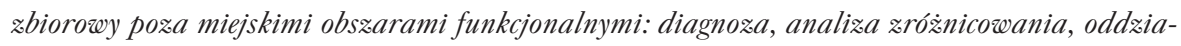
tywanie spoteczne, rekomendacje, SGH, Warszawa.

Zajfert M., 2012, Specyfika sektora transportu kolejowego i możliwe modele funkcjonowania jego segmentów, Zarządzanie Zmianami: Zeszyty Naukowe, 3-4, 57.

Zajfert M., 2013, Kolejowe præewozy pasażerskie o charakteræe użytku publičnego - Doświadczenia ostatnich 20 lat transformacji kolei w Polsce, Studia Ekonomiczne, 3, LLXXVIII. 
Zajfert M., 2015, Ekonomicæne uwarunkowania funkcjonowania pasa:erskiego transportu regionalnego w Polsce, Gospodarka Narodowa, 6, 280, 71-99.

Żurkowski A., 2009, Modelowanie przewozów międzyaglomeracyjnych, Problemy Kolejnictwa, $148,5-47$.

Mateusz Smolarski

Uniwersytet Wroctawski

Zaktad Zagospodarowania Præestrwennego

ul. Ku:nic:a 49/55, 50-138 Wroctaw

mateusz.smolarski@gmail.com 
